\title{
Student-Centred Learning In Mathematics - Constructivism In The Classroom
}

Sharifah Fauziah Hanim Syed Zain, Cyberjaya University, College of Medical Sciences, Malaysia Farah Eliza Mohd Rasidi, Cyberjaya University, College of Medical Sciences, Malaysia Ismin Izwani Zainol Abidin, Cyberjaya University, College of Medical Sciences, Malaysia

\begin{abstract}
Various techniques have been introduced among educators to relate concepts to application, from inductive learning, discovery learning, and student-centred learning (SCL). Mathematics has always been taught the traditional way - teacher is the main person to teach through lectures and activities, with students mostly in the passive receiver mode (O'Neill \& Mc Mahon, 2005). Students in Malaysia are very exam-oriented and adamant to the end grade, the score they must achieve to secure a good Grade Point Average through memorising and regurgitating facts. Those who dislike mathematics have to undergo remedial sessions and repeat the course, yet still only manage a low passing grade. This study explored the effects of the student-centred learning $(S C L)$ approach in Mathematics on learning skills among pre-university students and teachers; and their perceptions of the SCL technique in the course. Through a quantitative approach and interviews with the selected samples, the data was analysed and discussed against the Constructivist theory as the theoretical framework. Results revealed that the learning skills were demonstrated in SCL through students' heightened interaction and cooperation, in and outside of the classroom, better planning of the lesson and their learning, with some elements of analytic skills being portrayed. These students are less passive receivers of knowledge; more responsive, and able to relate to their experiences. The study also highlighted the gap which existed between what students expected in their learning and what teachers have taught; in terms of curriculum design as well as assessment.
\end{abstract}

Keywords: Student-Centred Learning in Mathematics; Learning Skills in Student-Centred Learning

\section{INTRODUCTION}

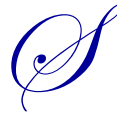

tudent Centred Learning (SCL) or Student Centred Team-Based Learning (SCTL) has been considered a big shift from the traditional teacher centred learning; the latter occurs where the teacher is the centre of attention in disseminating information directly to the students. Student centred learning, however, is a learning approach where students are the focus of the learning process; preparing the lesson prior to the intended lecture, participating actively in class and working to achieve a common academic goal. Students in this mode of learning are seen to be more extrinsically motivated and learn important skills such as critical thinking and problem solving (Zakaria \& Iksan, 2007; Johnson, Kimball, Melendez, Myers, Rhea, \& Travis, 2009; Froyd \& Simpson, 2010). Based on the premise that all humans construct their own perspective of the world is the Constructivism theory. A person adjusts his mental model to incorporate new experiences and make sense of this new information, and his schema is constantly readjusting. Learners are not passive recipients of information but are active agents engaging in constructing their own knowledge. In the classroom, a student is encouraged to think beyond what is presented, and explore further the concepts and working collaboratively with the teacher. Constructivism focuses on preparing the learner to problem solving situations, negotiate and generate solutions through sharing and exchange of ideas. Constructivism presents the idea that the learner is much more actively involved in a joint collaboration with the teacher of creating new meanings (Atherthon, 2010)

The concept of students as the centre of learning or Student Centred Learning started off in 1905 by Hayward and later developed by Carl Rogers, with his theory of client-centred counselling. This later influenced the 
approach into a general theory of education (O'Sullivan, 2003). Rogers's theory of a change of power from the teacher as the expert, to the students as learners, had led to less threatening situations in the classroom, on the basis that one cannot teach a person directly, only facilitate.

The shift from teaching to a greater emphasis on learning encouraged more widespread growth of Student Centred Learning as an alternative approach. Student-centred is also known as cooperative learning, learner-centred, peer-led team learning, and many more. Learners, according to the Constructivist theory, are not passive recipients of information but are active agents engaging in constructing their own knowledge. Students learn as they encounter the knowledge, i.e, they construct meaning and the system of meaning. It is recognized that students learn in different ways and have different learning styles, giving a high level of choice to learn. SCL involves a high degree of discovering knowledge on their own which improves learning and knowledge retention, with less dependency on the teacher as the owner of knowledge. Learning involves the construction of new understanding by combining prior learning with new information (Brooks \& Brooks, 1999). As students construct their own meaning by talking, listening, writing, reading and reflecting on content, ideas and problems, they simultaneously become social, using language.

Student Centred Learning stemmed from the Constructivist learning theory in which students construct knowledge for themselves, and learning is established when meaning is found. Learning, according to this theory, involves language that is used which influences learning. People talk to themselves as they learn, and language and learning are inextricably intertwined. Learning is also contextual, people do not learn through isolated facts and theories of abstract pieces of information, separated from the rest of their lives. People learn in relationship to what else they know, what they believe, their prejudices and fears. Unlike the Cognitivist theory, learning is an active process that requires students to utilize their sensory inputs and constructs meaning from it. It is also a social activity, encouraging learning through interactions with peers, teachers, or other people. Also, learning occurs over time. Students need to revise and revisit the ideas they have constructed, and play with the idea repeatedly over new experiences.

SCL as an instructional approach allows students to use content, construct activities, materials and set the pace for learning. Students are the main recipients of the learning process, and teachers cannot offload information into the students' brains and expect them to process and apply it. Brooks and Brooks (1999) highlight methods of learning that are most effective and amount of information that is best retained are through discussion group (50\%), practice by doing $(75 \%)$ and teaching others or immediate use of learning (90\%). Lectures are only $5 \%$ effective, as it is not part of the active learning process. If students value their team members and have become interdependent on each other, they are likely to encourage and support each other to succeed. Teaching others involves greater preparation, commitment and desire to prove their ability, to share the knowledge and gain new insights from other members' contributions (Slavin, 1995). Froyd \& Simpson (2010) emphasise that SCL puts forth students' prior knowledge as it influences future learning. When students are formed into small groups for learning activities and preparation of SCL presentation, it allows students to interact more actively, share ideas and show some commitment towards the team members. It also sets the teachers to think of the learning processes that the students go through in order to learn effectively. It is no longer on what and how to teach or why it is taught in the first place (Di Napoli, 2004). The development of the cognitive areas in learning through interactions with other group members enhances the mental processing of information, far stronger than just being motivated to learn.

\section{Objectives of the Study}

- To determine the factors that improve students' learning skills in Mathematics through Student Centred Learning (SCL)

- $\quad$ To investigate the perception of students on Student Centred Learning (SCL) in Mathematics

- To determine the effectiveness of Student Centred Learning (SCL) in Mathematics in helping students in their overall performance of the course 


\section{RESULTS AND DISCUSSION}

Data from students' responses in questionnaire, as well as teacher's responses were collated and tabulated. Students' responses from the interview were transcribed and analysed based on content analysis. Out of 140 questionnaires distributed (this number excludes repeaters and any other students who had been exposed to SCL prior to entering the place of study), only 128 were returned (91.42\%).

The purpose of this study is to determine the effects of Student Centred Learning approach in Mathematics on learning skills. Analysis for quantitative data was conducted using SPSS version 17.0 to analyse in terms of mean, median and standard deviation. Data was analysed to determine factors that help to improve learning skills in Mathematics as well as to ascertain the perception of students in the application of SCL. Results of the analysis are presented in tables and excerpts of the interview are explained in order to answer the research questions. An interview was conducted with five students, of homogeneous group, to determine how they feel about the use of SCL in Mathematics at the pre-university level. These students have not had any prior experience to this learning from other institution; they all scored between B to B + in the previous semester's Mathematic final exam, and of the age range of between 18 to 19 years old at the time of interview. All participants have had experience in presenting in an SCL session in the past semester as well as in Mathematics 1. Questions for the interview are of the same sequence and category as the quantitative analysis.

\section{Analysis of students' responses}

Findings are divided and discussed based on the first research question: Does SCL help to improve students' learning skills in Mathematics?

Table 1 Analysis of questionnaire: students' responses

\begin{tabular}{|l|c|c|c|c|c|}
\hline & M & Missing & Mean & Median & Std. Deviation \\
\hline $\begin{array}{l}\text { Section A: Learning about the world ("I've learned how Math } \\
\text { is part of my in and out-of-school life") }\end{array}$ & 128 & 0 & 2.69 & 3.00 & .929 \\
\hline $\begin{array}{l}\text { Section B: Learning to speak out ("It's OK for other students } \\
\text { to ask for clarification") }\end{array}$ & 127 & 1 & 3.96 & 4.00 & .840 \\
\hline $\begin{array}{l}\text { Section C: Learning to learn ("Each group member helps plan } \\
\text { what the class is going to learn") }\end{array}$ & 128 & 0 & 3.61 & 4.00 & 1.052 \\
\hline $\begin{array}{l}\text { Section D: Learning to communicate ("Students talk with } \\
\text { other students about how to solve problems (not limited to } \\
\text { just among group members)") }\end{array}$ & 127 & 1 & 3.57 & 4.00 & 1.050 \\
\hline
\end{tabular}

Section A: Learning about the world: It showed that SCL in Mathematics has helped the students to learn how Math is part of their life in and out of the classroom. However, the highest mode is 3, indicating that students only sometimes find Mathematics applicable to the life inside and outside of the learning environment. In the interview, two students felt that Mathematics that is being taught is related to the undergraduate course which they will embark later, i.e., MBBS and Pharmacy.

"Math is related to pharmacy because some of the calculations are related to chemistry and physics"

Two other students, however, felt that the course is related to certain elements in medicine, though more could be done to improve the curriculum, and should be more related to the undergraduate studies, to which the current curriculum is not adept to.

"I feel Math can be more interesting if they teach us how to calculate and relate to medicine..."

"I think I prefer if the topic is more related to medicine because we're doing MBBS after this. ...if we know this formula can be used in the other medical course then I think we can concentrate in class and then the SCTL can help us a lot ..." 
"Sometimes I feel the activities can be very useful outside the class but so far it's not strong enough. ...I prefer more medical related."

Section B: Learning to speak out: In the students' response, it was found students are comfortable asking the group presenting during an SCL session, without feeling inhibited. All participants in the interview felt they were able to question the group which is presenting on matters they felt was confusing. Students take the opportunity to ask their friends at the instant if they find the material too difficult to understand.

"If you don't understand, then we can ask them in class."

"We are allowed to ask even when they are presenting."

Section $C$ : Learning to learn: This section indicates that each member contributes to the planning and preparation, prior to an SCL presentation. Students in general are given notice on the topic and date of presentation a minimum of two weeks, or in some courses, at the beginning of the semester. Preparation is given ample time, therefore group members have to be ready with the presentation and materials. It is impossible for students to estimate how much learning is taking place during the SCL presentation; however, interjection from the lecturer mid way indicates that the content being presented is wrong. Students are allowed to continue with the SCL session or asked to repeat.

Participants in the interview all agree that they divide the topic in such that everybody prepares a certain section, and combine them all prior to the actual day. Planning and discussion are essential; they practice their presentations with their group members before presenting it. They also ensure that everyone helps each other in the preparation or receive help from other friends.

"We divide the sections so everyone must do something. Sometimes other students come to teach the group after the presentation because they feel the group don't prepare carefully."

"We take one section each ...we combine all the slides, then practice... Sometimes we ask the group to explain again during the presentation."

Section D: Learning to communicate: The mean results from the students indicate that they feel uninhibited in talking to others (non group members) to find solutions relating to an SCL presentation. An element of SCL involves interaction between group members and other students in class. This is evident from the responses received from the participants; students are required to give comments of the presentation, they are able to talk about it after the session is over and one student commented on the importance of discussing about the SCL activity immediately after the session for further discussion of the topic.

"We tell her [lecturer] our opinion of the presentation."

"I think it's important to talk about the SCTL when it is just finished so that we get the immediate comments."

"if the topic is difficult, we ask the group to teach us again after class or before the exam."

"... when the topic is confusing then it's easier to call your friend and ask."

\section{Analysis of teachers' responses}

Three teachers, teaching Mathematics for the Foundation in Science programme were also given a set of questionnaire, to compare the findings from the students' version data and the academics. They were also interviewed at a separate time and place for the qualitative data collection. 
Table 2 Analysis of questionnaire: teachers' responses

\begin{tabular}{|c|c|c|c|c|c|}
\hline & $\mathbf{N}$ & Missing & Mean & Median & Std. Deviation \\
\hline $\begin{array}{l}\text { Section A: Learning about the world ("I've learned how } \\
\text { Math is part of my in and out-of-school life") }\end{array}$ & 3 & 0 & 3.33 & 3.00 & .577 \\
\hline $\begin{array}{l}\text { Section B: Learning to speak out ("It's OK for other } \\
\text { students to ask for clarification") }\end{array}$ & 3 & 0 & 4.00 & 4.00 & 1.000 \\
\hline $\begin{array}{l}\text { Section C: Learning to learn ("I allow the group which is } \\
\text { presenting to help decide which activities work best") }\end{array}$ & 3 & 0 & 4.33 & 4.00 & .577 \\
\hline $\begin{array}{l}\text { Section D: Learning to communicate ("The group } \\
\text { presenting is asked by other students to explain or repeat } \\
\text { the explanation during the presentation") }\end{array}$ & 3 & 0 & 4.33 & 5.00 & 1.15 \\
\hline
\end{tabular}

Section A: The teachers responded similarly to those from the students; with a slightly higher mean (3.33) as they felt that they have taught sufficient knowledge to relate Math to the students' life in and out of campus.

Section B: The teachers' responses were similar to students' response, in which they too found other students feel comfortable asking for clarification to the group presenting during an SCL session.

Section $C$ : The teachers' responses differed from the students' response, in which they allow the group presenting to help decide which activities work best. There is a possibility that teachers do not see the planning of an SCL session when students discuss outside the classroom; or that students do not realise that the group presenting is given opportunity to decide what works best.

Section D: The teachers' responses differed from the students; there is a possibility that teachers observed this occurring very frequently during an SCL session, that they see students having more freedom to ask their colleagues as the presentation was taking place.

It is found that there are similar responses received from both the students as well as the teachers' - that both groups of participants perceive that learning through SCL exposes them to the application of concept in and out of the classroom setting, with some elements that are related outside of the students' school life. The responses did not show that the teachers taught beyond the campus, i.e., what is expected of them as students embark into their career as doctors or pharmacists, neither could the teachers relate much to what will be taught in medicine or pharmacy programmes, as early indication that require students to apply the mathematical concepts. Nevertheless students felt safe to ask during the learning in class, as validated by the teachers' responses. Learning skills in this study showed that both students and teachers agreed that communication was vital in finding the best solution, and students were not confined to within their group members in their discussion.

Another section of the questionnaire answered the second research question: How effective is SCL in Mathematics in helping in overall performance of the course?

Table 3 Analysis of overall performance: students' responses

\begin{tabular}{|l|c|c|c|c|c|}
\hline & M & Missing & Mean & Median & Std. Deviation \\
\hline $\begin{array}{l}\text { Overall performance of the course ("Topics covered } \\
\text { during SCTL stay longer in memory and can be applied } \\
\text { in subsequent lessons") }\end{array}$ & 127 & 1 & 2.92 & 3.00 & \\
\hline
\end{tabular}

Participants of the students' interview found that they felt more confident and could score better in the quizzes that follow due to the extensive preparation for the SCL. Only one student said that it was not possible to score in the exam as the questions would have been from various topics including those that the group presented and did not present. The responses were consistent with the quantitative data presented in Table 3, that memory is stronger through SCL, and that they could relate to other topics that follow.

"If I present the topic then I know I can score the quiz."

"I feel confident if I present and then I can score the quiz but not the exam yet."

(C) 2012 The Clute Institute http://www.cluteinstitute.com/ 
"I feel the topic we teach will be easier to understand the other topics after that. ...but the SCTL help [me] to remember better because you have to do the teaching or you have to check your friends' presentation. So that means you also have to prepare a bit."

Table 4 Analysis of overall performance: teachers' responses

\begin{tabular}{|l|c|c|c|c|c|}
\hline & N & Missing & Mean & Median & $\begin{array}{c}\text { Std. } \\
\text { Deviation }\end{array}$ \\
\hline $\begin{array}{l}\text { Overall performance of the course ("Topics covered during } \\
\text { SCTL stay longer in memory and can be applied in } \\
\text { subsequent lessons") }\end{array}$ & 3 & 0 & 3.00 & 3.00 & .000 \\
\hline
\end{tabular}

Though there are no academic grades to compare for the findings, based on the responses received from the questionnaire, the teachers' responses were similar to the students', that they saw students able to remember the topic better when they presented the content, and that students were able to apply the concepts onto other lessons as they progressed.

"I think the effect of SCTL is the students can follow the next chapters very easily when they have done SCTL. It's very obvious...because when you ask them, they could answer very quickly. ... they also feel a bit more confident when they have SCTL. 'I teach this so I must know this well...' that sort of thing."

In short, the responses given by both students and teachers generally showed that students were confident and able to remember better each topic if presented through SCL. Preparation, as well as sharing of opinion promotes higher students' awareness in the future topics that would be taught. It also helps teachers in the transition from one topic to another, guiding the students from a known topic to the unknown or new one.

\section{CONCLUSION}

Students showed agreement that SCL in Mathematics help them to realise how Math is part of their lives, in and outside of school. This augurs well with teachers who also support that Mathematics is taught to enable students apply and relate the concepts to their surroundings. Brooks and Brooks (1999) stress that many educators believe that the best way to learn is by having students construct their own knowledge instead of having someone construct it for them. Students learn best when they are able to relate what they learn in the classroom to the immediate environment and create meaning from different experiences. By talking and discussing with others, the content is no longer an item to be memorised, too abstract and isolated; the skill now is to integrate and encourage higher order thinking, interpreting and also blending in what they already know. Most students mentioned that the preparation and presentation were both challenging and relevant, leading to higher participation among the class members in the question and answer sessions, apart from helping them to understand the topics better. Teachers in this study too found that they tried to embed the SCL sessions to the outside world; particularly as these students would later be joining the medical and pharmacy programmes.

The relationship to the world, though as the teachers readily admit, is limited; very few relates to illness of patients, prescribing without overdosing to patients, calculating the efficacy and potency of the drug in the body and calculating the rate at which blood flows through a small blood vessel, and many more. A special consultation with the medical and pharmacy faculties are needed in order to make this teaching and learning more effective and to meet the demands of the studies, at the same time, preparing students on what to expect in the undergraduate level. Teachers see students' active interaction when planning an SCL session with their peers as very positive, indicating team work and cooperation. Kember and McNaught, as cited in Kember (2009) stressed that meaningful learning is bound to take place when students are actively engaged with a variety of learning tasks, especially in discussions on any important learning activity.

Another skill that is derived from this study is that students feel comfortable to get clarification from their peers on content that is confusing. This means that the classroom ambience during SCL is no longer threatening, that students are able contribute or contest their friends. Being able to speak out shows that students are not mere recipients of knowledge who are merely expected to process and apply. A constructivist-based classroom will fully 
endorse critical thinking through questions and mostly between students (Brooks and Brooks, 1999). Learning, according to the Constructivist theory, is very personal yet social, as students firstly try to make meanings out of what is brought in front of them, then through social interaction with peers and teachers, put the new information into a proper order or structure (Hein, 1991). Hence, in teaching, a teacher must think about the learner in thinking about the learning, not just the lesson to be taught.

In SCL, the approach is attempting to take into account the individual's pace and everyone is not forced to progress at the same rate. "Learning is recognized as an active dynamic process in which connections between different facts, ideas and processes) are constantly changing and their structure is continually reformatted. Such connections are fostered through dialogue between teacher and students, students with their peers." (Di Napoli, 2004, p.3). Learning skills in SCL develop students in their learning process through talking, listening, reading, writing and reflecting all the content, ideas, issues that are presented to them, as well as building on the existing perceptions that they may already have to their learning. Most importantly, SCL encourages how effective learning should be promoted, not the teacher's performance in class (Di Napoli, 2004). When students discuss with the team members on items to present, there will be the tendency to summarise what they have read, and present it orally to the others. This then is reciprocated by other members either in two's or more, and the act enables them to share the amount of understanding that they have in them. By sharing, they are able to check on other people's understanding and perceptions, and consolidate or strengthen what is already known to what they have just listened to (Cornish, 2007; Quitadamo, Brahler \& Crouch, 2009). Creative thinking occurs when they have to accommodate other people's thoughts and accept others' way of thinking. Students are also able to test themselves through activities that challenge them for example questions that test their hypotheses, identifying similarities and differences, making analysis, giving evaluations and making judgments; all of which are the higher levels of the Bloom's Taxonomy of the Cognitive Domain. Froyd and Simpson (2010) emphasised that in student centred environment, knowledge of learners influence future learning; and this can be in Mathematics or other courses where calculation and application of concepts are needed. In addition, strong, committed team work and positive interaction among members and other colleagues are all catalysts to students' retain of information. Learning in a constructivist environment does not speak of academic performance; the most important action of constructing meaning happens in the mind. Physical actions, hands-on experiences are also necessary for learning, especially for children; nevertheless activities which engage the mind as well as the hands are most beneficial. Examinations and grades are not considered the essential in a constructivist learning. The system in Malaysia is still very much focused on scores and getting A's, though the education system is changing, the attitudes and teachers' approaches are still tied down to teacher centred learning though the name SCL is used. SCL promotes and enables students to succeed through various learning styles, visual, auditory, and kinesthetic. Visual and auditory students gain from the presentations in the SCL sessions, they are able to visualize and get a clearer picture of the concept being explained, and as they discuss the problems in groups. Equally, students with kinesthetic learning style can excel through hands on activities that are conducted by the presenting groups through games or short quizzes. SCL is group-based, and when students work in their respective groups, they construct the answers or solutions together, rather than individually. The threat of being criticised on a personal basis or being ridiculed in front of others is removed, and allows the team to be responsible for the answer.

Student Centred Learning is not merely about classroom interaction. The curriculum, assessment and syllabus design are affected as well. This study has revealed that such activity can be implemented in Mathematics, a course which many assume can only be successful through lecture-based approach (refer Table 5 for comparison of SCL in Math to the Constructivist theory). The students' entry knowledge was taken into consideration prior to designing the curricula, as well as methods of assessment during the SCL presentation. Student cooperation outside the classroom as they prepare the presentation has been observed to have improved, students showed greater interaction, not only with their respective team members, but other groups as well. The interview with some of the students also showed that they are able to plan well, apart from giving serious effort to practice and evaluate each other's 'performance' in class. Teachers too find that students are active during an SCL presentation; they are not inhibited to ask their friends to explain or repeat a presentation. These students are not passive receivers of knowledge, they are responsive, and able relate to their experiences as they receive new knowledge. Meaningful learning occurs when students are seen to be actively engaged with a variety of learning tasks such as discussions, preparation for presentation, and deliberation of other groups' ideas. Cooper, MacGregor, Smith \& Robinson, as cited by Froyd \& Simpson (2010) show that Student Centred Learning has led to increased learning among students, better understanding of concepts, able to handle more complex situations and critical thinking, higher attendance to 
class, more independent and better confidence. It is no doubt that with such accolades to the strategy, it should be promoted extensively to all faculties in all educational institutions.

Table 5: Comparison between SCL in Math to the Constructivist theory

\begin{tabular}{|l|l|l|}
\hline Learning skills & \multicolumn{1}{|c|}{ SCL in Mathematics } & \multicolumn{1}{|c|}{ Constructivist theory } \\
\hline $\begin{array}{l}\text { Learning about } \\
\text { the world }\end{array}$ & $\begin{array}{l}\text { Exposes students to the application of concepts in and out of } \\
\text { classroom (but not strong enough to relate to the } \\
\text { undergraduate studies) }\end{array}$ & $\begin{array}{l}\text { Construct knowledge out of students' } \\
\text { experiences }\end{array}$ \\
\hline $\begin{array}{l}\text { Learning to } \\
\text { speak out/ } \\
\text { Learning to } \\
\text { learn }\end{array}$ & $\begin{array}{l}\text { Students have freedom to ask/ get answers from other } \\
\text { members } \\
\text { Each group member helps plan what the class is going to } \\
\text { learn }\end{array}$ & $\begin{array}{l}\text { Interdependence among students and team } \\
\text { members } \\
\text { Involvement and participation are necessary } \\
\text { for learning }\end{array}$ \\
\hline $\begin{array}{l}\text { Learning to } \\
\text { communicate }\end{array}$ & $\begin{array}{l}\text { Students talk with other students about how to solve } \\
\text { problems } \\
\text { Communication is vital in the learning/ during SCL }\end{array}$ & $\begin{array}{l}\text { Better interpersonal skills } \\
\text { Students experience confluence in cognitive } \\
\text { and affective domains }\end{array}$ \\
\hline $\begin{array}{l}\text { Overall } \\
\text { performance of } \\
\text { the course }\end{array}$ & $\begin{array}{l}\text { Higher confidence to follow subsequent lessons } \\
\text { Helps in transition to new topics }\end{array}$ & $\begin{array}{l}\text { Meaningful learning occurs through a } \\
\text { smooth transition from existing experience } \\
\text { to new ones }\end{array}$ \\
\hline
\end{tabular}

\section{AUTHOR INFORMATION}

Sharifah Fauziah Hanim Syed Zain - a lecturer at the Centre for Languages and General Studies, currently teaching English for Special Purposes to undergraduate students of MBBS and Pharmacy. She has been involved in teaching for the past 21 years, 14 of which were adult learners. Her keenness involves education management, instructional design and pedagogy. She holds a $\mathrm{PhD}$ in Curriculum and Instruction. E-mail: fauziah@cybermed.edu.my (Corresponding author)

Farah Eliza Mohamad Rasidi - an assistant lecturer, teaching Chemistry for the Foundation in Science programme, since 2009. She holds with a degree in Engineering and has currently completed M.Sc in Chemical Engineering. Her passion includes teaching and research and development. E-mail: farah@cybermed.edu.my

Ismin Izwani Zainol Abidin - a lecturer for the Faculty of Pharmacy since 2009, and holds a Bachelor in Chemistry and Mathematics. She holds an M.Sc in Pharmaceutical Analysis and is currently actively involved with the improvement of curriculum design and I.S.O. academic documentations at the faculty. Her passion is sharing of knowledge and developments of pedagogy. E-mail: ismin@cybermed.edu.my

\section{REFERENCES}

1. Atherton, J. S. (2010) Learning and Teaching; Constructivism in learning. Retrieved from: http://www.learningandteaching.info/learning/constructivism.htm

2. Brooks, J. G. \& Brooks, M. G. (1999). In search of understanding: the case for constructivist classrooms, with a new introduction by the authors. Alexandria: Association for supervision \& curriculum development.

3. Cornish, L. (2007). Creative teaching, effective learning in higher education. 32nd international conference on Improving University Teaching: The Creative Campus, Jaén, Spain, 4-7 July. Paper Retrieved from ProQuest Education Journals database.

4. Di Napoli, R. (2004). What is student centred learning? 1 - 7. Retrieved from: http://www.wmin.ac.uk/pdf/WhatIsSCL.pdf

5. $\quad$ Ernest, P. A. (1991). Philosophy of Mathematics education. U.S.A: Routledge: USA

6. Felder, R. M., (1997). Beating the numbers game: effective teaching in large classes. Retrieved from: http://www4ncsu.edu/unity/lockers/users/f/felder/public/Papers/Largeclasses.htm

7. Froyd, J., \& Simpson, N. (2010). Student-centered learning addressing faculty questions about studentcentered learning. Retrieved from http://ccliconference.org/files/2010/03/Froyd_Stu-CentredLearning.pdf

8. Hein, G. (1991). Constructivist learning theory. Retrieved from: http://www.exploratorium.edu/IFI/resources/constructivistlearning.html 
9. Ismail, N. A., \&Awang, H. (2009). Mathematics achievement among Malaysian students: what can they learn from Singapore? International Education Studies 2(1), 8 - 17. Retrieved from: http://www/ccsenet.org/journal/index/php/ies/article/viewfile/282/359

10. Johnson, A., Kimball, R., Melendez, B., Myers, L., Rhea, K. \& Travis, B., (2009). Breaking with tradition: preparing faculty to teach in a student-centered or problem-solving environment. Primus: Problems, Resources, and Issues in Mathematics Undergraduate Studies. 19(2). Retrieved from ProQuest Education Journals database

11. Kember, D. (2009). Promoting student-centred forms of learning across an entire university. High Educ. 58, 1 - 13. Doi: 10.1007/s10734-008-9177-6

12. Lim, S.C. (2009). Assessment in Malaysian school Mathematics: issues and concerns, 1 -6. Retrieved from: http://www.criced.tsukuba.ac.jp/math/apec/apec2009/doc/pdf_20-21/LimChapSam-paper.pdf

13. McClure, R., Johnson, B., \& Jackson, D. (2003). Assessing the effectiveness of a student-centered college classroom. 1 - 12. Retrieved from:

http://tpdweb.umi.com.newdc.oum.edu.my/tpweb?Did=ED477743\&Fmt=1\&Mtd=1\&Idx=11\&Sid=2\&RQ $\mathrm{T}=877 \&$ EricUrl=http://www.eric.ed.gov/contentdelivery/servlet/ERICServlet?accno=ED477743\&TS=129 $\underline{1816096}$

14. O’Neill, G., \& McMahon, T. (2005). Student-centered learning: what does it mean for students and lecturers? 27- 36. Retrieved from http://www.aishe.org/readings/2005-1/

15. Schumacher, P., \& Kennedy, K.T. (2008). Lessons learned concerning a student centered teaching style. Education. 129(1) 102 - 108. Retrieved from ProQuest Education Journals database

16. Slavin, R. E. (1995). Research on cooperative learning and achievement: what we know, what we need to know. Retrieved from ProQuest Education Journals database.

17. Quitadamo, I. J., Brahler, J.C., \& Crouch, G.J. (2009). Peer-led team learning: A prospective method for increasing critical thinking in undergraduate science courses. Science Educator. 18(1), 29 - 39. Retrieved from ProQuest Education Journals database.

18. Zakaria, E., \& Iksan, Z. (2007). Promoting cooperative learning in Science and Mathematics Education: A Malaysian perspective. Eurasia Journal of Mathematics, Science \& Technology Education. 3(1), 35 - 39.

Retrieved from ProQuest Education Journals database. 


\section{NOTES}

